\title{
A presença do amor em Vidas secas
}

\author{
Luís Bueno
}

RESUMO: A pergunta que precisa ser feita se se quiser compreender o amor em Vidas secas é esta: quem sabe lá como são as coisas? Quem sabe lá como se sente amor? É esse o traço essencial do amor "diferente" que se vê na obra de Graciliano Ramos: por se constituir no conjunto amplo das preocupações, frustrações e anseios das personagens, ele repele a ideia de uma pureza essencial do indivíduo

PALAVRAS-CHAVE: Graciliano Ramos; Vidas secas; amor

\begin{abstract}
The question which needs to be asked if you want to understand love in Vidas secas is: who knows how things are? Who knows how one feels love? That is the essential feature of the "diferente" love that is seen in the work of Graciliano Ramos: because it is made of a wide range of concerns, frustrations and desires reagrding the characters, it rejects the idea of an essential purity.
\end{abstract}

KEYWORDS: Graciliano Ramos; Vidas secas; love 
Para Patrícia

1.

Em seu conhecido depoimento a João Condé, Graciliano Ramos afirma que o amor está ausente de Vidas secas:

Fiz o livrinho, sem paisagens, sem diálogos. E sem amor. Nisso, pelo menos, ele deve ter alguma originalidade. Ausência de tabaréus bem falantes, queimadas, cheias, poentes vermelhos, namoro de caboclos. A minha gente, quase muda, vive numa casa velha de fazenda; as pessoas adultas, preocupadas com o estômago, não têm tempo de abraçar-se. Até a cachorra é uma criatura decente, porque na vizinhança não existem galãs caninos. ${ }^{1}$

É verdade que as pessoas adultas não se abraçam - ou quase não se abraçam - em Vidas secas, nem tampouco há ali - por incrível que possa parecer em romance ambientado no interior do Brasil - galãs caninos que ameacem a decência de Baleia. Mas isso está longe de encerrar a discussão. E, no caso de Graciliano Ramos, trata-se de discussão especialmente espinhosa dada a imagem de aridez e pessimismo que se fixou a seu respeito.

No prefácio a Cartas de amor a Heloísa, o volume que traz as cartas que o romancista escreveu no início de 1928 para aquela que seria sua segunda mulher, José Paulo Paes define sinteticamente essa imagem, chamando-a de "mito Graciliano Ramos":

Pelo que tudo indica, o mito Graciliano Ramos foi forjado à sombra da surrada definição de Bouffon de que o estilo é o homem. Nesse caso também, o demônio da simetria levou à identificação homológica do efeito com a causa. Ou seja, tomou-se como ponto de partida uma prosa ficcional cuja tensa economia, avessa a qualquer tipo de sentimentalidade, estava a serviço de uma visão de mundo as mais das vezes pessimista, autocrítica e sarcástica. ${ }^{2}$

1. Ramos, Graciliano. "Depoimento”. In: Ramos, Graciliano. Vidas secas (fac-símile da primeira edição). São Paulo: Governo do Estado de São Paulo, 1988.

2. PAEs, José Paulo. "Amor/humor por via postal". In: Ramos, Graciliano. Cartas de amor a Heloísa. Rio de Janeiro: Record, 1994, p. 9. 
Note-se que esse mito é evocado exatamente para tratar de cartas de amor, preparando o caminho para o confronto entre a figura que ama e a que é avessa ao sentimentalismo:

Para quem ainda acredite na verdade global do mito Graciliano Ramos, a leitura de suas cartas de amor à noiva, Heloísa Medeiros, há de ser no mínimo desconcertante. O derramamento sentimental delas obedece ao pé da letra os cânones tradicionais da epistolografia do amor-paixão, a qual costuma ser tanto mais hiperbólica nos seus arroubos quanto casta nos seus propósitos confessos. Mas, uma vez admitida a homologia entre criador e criação, como conciliar a sentimentalidade dessas cartas com a desencantada e/ou cínica visão do amor que, na primeira pessoa da experiência vivida, nos propõem João Valério, Paulo Honório e Luís da Silva em Caetés, S. Bernardo e Angústia, respectivamente?3

O que o crítico-poeta constrói é uma relação de oposição, uma espécie de incompatibilidade entre essas duas faces que termina por sugerir um esvaziamento do sentimento amoroso na totalidade dos romances - e a ausência de Vidas secas é especialmente significativa pois sugere que José Paulo Paes concorda que não há amor no livro, o que o dispensa de considerá-lo.

A questão que se coloca de imediato, sem a qual não é possível enfrentar tal discussão, é se essa oposição é assim tão rígida e de fato amor e sentimentalismo identificam-se de forma tão natural. Para tratá-la, vale a pena retomar o célebre artigo de Otto Maria Carpeaux, no passo em que diz que o "lirismo de Graciliano Ramos, porém, é bem estranho. Não tem nada de musical, nada do desejo de dissolver em canto o mundo das coisas". ${ }^{4}$ Diante de um texto conciso, de corte clássico, movido por um "desejo de eliminar tudo o que não é essencial", 5 ou, em outras palavras, diante do verdadeiro horror ao derramamento verbal e ao sentimentalismo que essa obra encarna, Carpeaux, ao invés de dizer que ela não contém lirismo, afirma que seu lirismo é "estranho".

Olhado de perspectiva análoga, o amor na obra de Graciliano Ramos pode ser percebido como "estranho", ou, o que é preferível, diferente. Assim, a leitura fica livre das oposições, e talvez seja possível encontrar o amor num livro como Vidas secas.

\footnotetext{
3. Id., p. 11.

4. Carpeaux, Otto Maria. "Visão de Graciliano Ramos". In: Origens e fins. 2. ed. Rio de Janeiro: Casa do Estudante do Brasil, 1943, p. 339.

5. Ibid.
} 
2.

Antes porém de tratar desse romance, vale ver como esse amor diferente aparece na obra de Graciliano antes de Vidas secas. Tomemos Caetés, o mesmo romance que José Paulo Paes utiliza para pensar as cartas de amor a Heloísa. Dele ninguém diria que o amor está ausente. Sua cena de abertura consiste na narrativa de um impulso passional de João Valério: "Não me contive e dei-lhe dois beijos no cachaço". ${ }^{6}$ Levando-se em conta que a beijada é Luísa, uma mulher casada, que está em sua casa, com o marido a poucos metros de distância, e esse marido é o patrão do jovem Romeu, que depende desse emprego, fica claro o grau de passionalidade da cena. Mas não é só isso. Ainda no primeiro capítulo, Valério faz uso da retórica típica dos apaixonados: "Eu amava aquela mulher. Nunca lhe havia dito nada porque sou tímido, mas à noite fazia sozinho confidências apaixonadas e passava uma hora, antes de adormecer, a acariciá-la mentalmente" (p. 8o); chega mesmo ao fervor: "A religiosidade de que minha alma é capaz ali se concentrava, diante de Luísa" (p. 80).

Depois de delineada assim de saída, essa paixão prosseguirá até chegar à conquista, com direito a ansiedade, encontros furtivos, evocação das estrelas e outros elementos das histórias de amor. A diferença se manifesta mais tarde, exatamente no momento em que esse amor, já concretizado mas ainda clandestino, pode se assumir: o marido morre. Caminho aberto, o que faz João Valério? O que não está previsto: some por dois meses, e o relacionamento acaba por aí. O que explicaria esse comportamento do apaixonado? A primeira resposta possível é a de que ele não a amava de verdade. Mas essa explicação fica bastante insatisfatória para quem escolheu a perspectiva segundo a qual a secura do estilo do autor não vem da ausência de lirismo, mas sim de um lirismo "estranho".

Uma outra resposta seria que, em Caetés, o amor não é rapto, puro sentimento. Não é aquilo que a Marguerite de Dama das camélias sente, algo que se separa radicalmente da vida social, colocando em movimento oposto o que a pessoa é e o que ela faz. Em Caetés não cabem relações de oposição porque o amor é algo que se sente e que, ao mesmo tempo, participa daquilo que o amador faz e quer para si. Ora, João Valério é um rapaz que não se conforma com a posição social que ocupa, de pequeno guarda-livros, justo ele, que vem de família que possuía terra e gado. Procura uma compensação

6. Ramos, Caetés. 2 ed. Rio de Janeiro, José Olympio, 1947, p. 79. Nas próximas citações se indicará, ao final, a página de onde foi extraída, sempre desta edição. 
para essa subalternidade na vida intelectual e se apaixona pela jovem esposa do patrão, tornando-a sua amante, o que também é uma forma de compensação. Morto o marido - patrão, a situação se transforma, novas oportunidades se abrem para o rapaz que, ao final do romance, estará contente, feito sócio da casa comercial em que era empregado - sem Luísa e sem projeto literário. As compensações não se fazem mais necessárias.

É como se o combustível - tanto para o amor quanto para a literatura - tivesse acabado. É assim o amor de João Valério. Jamais concebe o que viveu como uma experiência falsa e por isso dirá: "Dois meses sem ver Luísa. À noite distraía-me a repetir a mim mesmo que ainda a amava e havia de ser feliz com ela. Hipocrisia: todos os meus desejos tinham murchado" (pp. 211-2). Se murchou, é porque esteve inflado, se procura repetir que ainda a ama, é porque já amou. Quanto aos projetos literários, dirá que "um negociante não se deve meter em coisas de arte" (p. 214), mas que às vezes tira o romance histórico inacabado da gaveta: "Vem-me de longe em longe o desejo de retomar aquilo, mas contenho-me" (p. 214). Assim como não conseguira se conter e beijara Luísa no início da narrativa, aqui no final ele se contém para abandonar de vez os projetos literários. A mesma palavra e o mesmo gesto são evocados para iniciar a conquista amorosa e para enterrar a experiência literária. E, como ninguém tem que conter comportamentos impostos ou indesejados, fica claro que, para João Valério, tanto o amor que sentia por Luísa quanto o desejo de escrever um romance histórico são profundos. Se ele tem ou não consciência de o quanto esses desejos profundos vêm daquilo que podemos chamar de um recalque social não tem importância. Ele sente-se assim - ou crê que se sente. E isso basta, sobretudo na obra de um escritor que elogia Doidinho, de José Lins do Rego, precisamente porque nele "As coisas não aparecem como são (e quem sabe lá como são as coisas?), mas como o personagem principal as vê".

É essa a pergunta que precisa ser feita se quisermos compreender o amor em Vidas secas: quem sabe lá como são as coisas? Quem sabe lá como se sente amor? É esse o traço essencial do amor "diferente" que se vê na obra de Graciliano Ramos: por se constituir no conjunto amplo das preocupações, frustrações e anseios das personagens, ele repele a ideia de uma pureza essencial do indivíduo, de que haveria um ponto psicológico neutro em que um sentimento como o de Marguerite pudesse brotar. Ama-se porque há desejo sexual; porque há uma diferença entre o que obtemos e o que julgamos merecer e pressentimos em alguém ou um caminho para sair de um estado a outro ou uma possibilidade

7. Ramos, Graciliano. “Um romancista do Nordeste”. Literatura, Rio de Janeiro, 20 jun. 1934 (18), p. 1. 
de compensarmos a inferioridade por meio da submissão de um outro, sobretudo um que nos pareça difícil dominar; porque uma relação é sempre a esperança de começar algo que nos ultrapassa, exatamente como acontece com criaturas como João Valério, Paulo Honório e Luís da Silva, seres deslocados, vindos de um passado que não existe mais porque é perda ou que não interessa lembrar porque é carência.

Como talvez pudesse dizer o próprio Luís da Silva, cujo amor ultrapassou todos os limites até atingir o crime passional, o assassinato, o amor nasce da imundície dos monturos e da limpeza dos banhos demorados. Juntamente.

3.

A originalidade de Vidas secas nesse campo - mesmo em relação aos três romances anteriores do próprio Graciliano - estará porventura menos na ausência de amor do que em contrariar o velho lugar-comum segundo o qual os amores felizes não têm história. O amor já infeliz, ou aquele que luta para se concretizar num relacionamento, com o risco sempre presente de trazer a infelicidade aos amantes, ou a um deles pelo menos - esse é que gera as histórias de amor. A aventura amorosa, num caso e noutro, é alimentada pela infelicidade. É dela que brotam tanto as conquistas quanto os triângulos amorosos. Quando o amor é feliz, as aventuras cessam e a história acaba - eis o axioma dos contos de fada e da comédia romântica cinematográfica.

Focado na vida de uma única família com escasso contato com outras pessoas, Vidas secas está isento de aventuras amorosas: os meninos ainda não procuram amores e os pais vivem um casamento estável. É nesse sentido, portanto, que de fato não haveria amor em Vidas secas. Assim como não há cheias ou poentes. A rigor, nem mesmo seca há, já que a conhecemos apenas em seu final no primeiro capítulo.

No mesmo artigo em que aponta aquela grande qualidade de Doidinho, Graciliano expressara visão diferente acerca do livro anterior de José Lins:

O que há é que no primeiro, o Menino de engenho celebradíssimo, existem descrições que poderiam desaparecer sem desvantagem, uma queimada e uma enchente por exemplo, bem feitas, mas que já foram exploradas por literatos de outras épocas, o finado José de Alencar e o finado Graça Aranha inclusive. Esta opinião não tem importância. De ordinário o que se julga melhor no romance é exatamente a parte objetiva, e é provável que essas duas tiradas, ricas em minudências, semelhantes às fotografias que Balzac e os 
realistas aproveitaram, hajam concorrido para tornar Menino de engenho uma história admirada por toda a gente. ${ }^{8}$

Retomando a declaração de Graciliano Ramos sobre Vidas secas à luz desta sua opinião "sem importância", o que ela indica não é bem que o amor esteja ausente, mas o que de ordinário se entende por amor. Ora, as aventuras amorosas, com suas conquistas, traições, exaltações e desesperos, são, por assim dizer, as cheias e queimadas da tematização do amor. E no "livrinho" não há nada disso. E para que haveria?

Assim, não temos acesso ao tempo em que o casal se formou, e, pelo menos enquanto acompanhamos suas vidas, a nada que o ameace seriamente. Por isso, é preciso vê-lo enquanto casal constituído, vivendo para além do final feliz e aquém do rompimento, e localizar o amor nos meandros das experiências concretas e dos pensamentos que lhes vão no íntimo.

No campo do que é objetivo, um bom ponto de partida é aquilo que Graciliano diz que não há no livro, o abraço, a aproximação física, o desejo. E logo o primeiro capítulo da obra desmente o criador:

Miudinhos, perdidos no deserto queimado, os fugitivos agarraram-se, somaram as suas desgraças e os seus pavores. O coração de Fabiano bateu junto do coração de sinha Vitória, um abraço cansado aproximou os farrapos que os cobriam. Resistiram à fraqueza, afastaram-se envergonhados, sem ânimo de afrontar de novo a luz dura, receosos de perder a esperança que os alentava. ${ }^{9}$

Depois de localizarem um lugar onde passar a noite, na incerteza do instante que precede a caça de Baleia ao preá que os alimentaria, Fabiano e sinha Vitória se abraçam. Nesse abraço há desespero e medo partilhados, busca de consolo e apoio. Mas também há desejo, insinuado na vergonha que sentem do abraço, descrito como "fraqueza", como se a entrega ao outro significasse o pecado de se ocupar com o que não se deve e baixar a guarda, romper com a determinação de quem concentra todas as forças que restam em sobreviver e não tem direito de pensar noutra coisa. E esse narrador, sempre

8. Ibid.

9. RAMOS, Vidas secas. 2. ed. Rio de Janeiro: José Olympio, 1938, pp. 13-4. Nas próximas citações se indicará, ao final, a página de onde foi extraída, sempre desta edição. 
tão distante, não se intimida diante da expressão sentimental. Lida nesse contexto não se nota, porque não é e não tem esse efeito, mas, isolada, quem diria não se tratar de clichê sentimental a frase "o coração de Fabiano bateu junto do coração de sinha Vitória"?

O que esse parágrafo traz para o livro, logo em sua abertura, é uma demonstração objetiva, descrita de fora pelo narrador, do afeto que liga essas pessoas. A situação extrema em que vivem não anula esse afeto. É quase como se, ao negar que alguém se abrace no livro, Graciliano gritasse: "pois não estão vendo que há amor ali?”.

Essa cena tem repercussões mais adiante, quando encontramos uma sinha Vitória "amanhecida nos seus azeites", literalmente chutando a cachorra. Estava irritada porque o marido não se decidia a tomar providências para que fosse possível adquirir uma cama de couro que substituísse a de varas onde dormiam:

Tinha de passar a vida inteira dormindo em varas? Bem no meio do catre havia um nó, um calombo grosso na madeira. Ela se encolhia num canto, o marido noutro, não podiam estirar-se no centro. A princípio não se incomodara. Bamba, moída de trabalhos, deitarse-ia em pregos. Viera, porém, um começo de prosperidade. Comiam, engordavam (p. 63).

No capítulo inicial a extrema carência impedia a consumação do desejo, era preciso afastá-lo. Agora as coisas estavam mudadas, "tudo ali era estável, seguro" (p. 63), conforme ela própria pensara instantes antes. Com a prosperidade pode vir, é verdade, o descanso, que repele o desconforto. Mas o desejo também pode se manifestar, sem ser percebido como uma vergonha. Além de desconfortável por ser de varas, a cama tinha um calombo a separar marido e mulher. A restrição vem no plural, "não podiam estirar-se no centro" (p. 63). Quando dois partilham uma mesma cama, o centro ou é o local vazio ou o do encontro. Se apenas um estiver ali, o outro terá necessariamente que estar encolhido num canto. $^{10}$ É isso que incomoda sinha Vitória, agora que a seca não constitui ameaça. Notese, aliás, como algo semelhante confessara Luís da Silva: "E foi exatamente por me correr a vida quase bem que a mulherzinha me despertou interesse - novidade, pois sempre fui alheio aos casos de sentimento. Trabalhos, compreendem? Trabalhos e pobreza".

10. A ideia de que o nó no centro da cama é sentida como impedimento para a aproximação física dos amantes foi sugerida pelo próprio Graciliano, em depoimento ou entrevista lido entre tantas outras coisas para a escrita de um trabalho longo, mas cuja referência, perdida ou não anotada, não é possível indicar aqui. 11. Ramos, Graciliano. Angústia. 2. ed. Rio de Janeiro: José Olympio, 1941, p. 45. 
Há outros elementos miúdos no capítulo "Sinha Vitória" que constroem, esses sim, um amor urdido no dia a dia, em assuntos que, à primeira vista, nem relação têm com o amor. O ronco, por exemplo. Diante da irritação de sinha Vitória, Fabiano "amunhecara, porque mulher é bicho difícil de entender, deitara-se na rede e dormira" (p. 56). Ao dormir, ele ronca, e esse ronco a irrita: "Os roncos de Fabiano eram insuportáveis. Não havia homem que roncasse tanto" (p. 64). E a irritam, é claro, por algo que vai além do barulho propriamente dito: a desistência, por parte dele, da discussão.

Ocorre que, antes de manifestar irritação, ela encontrara um outro significado, este positivo, nesses mesmos roncos: "Fabiano roncava com segurança. Provavelmente a seca devia estar longe" (p. 63). O que se revela aqui é uma confiança absoluta em Fabiano, a ponto de tornar sua a tranquilidade dele, que ela intui pelo ronco, cujo "ritmo [...] influiu nas ideias de sinha Vitória" (p. 63). Ou seja, o ronco a irrita e a consola juntamente, mesmo num momento em que chega a afirmar que ele "é ruim" e "mal-agradecido" (p. 61). Haverá demonstração mais patente de ligação entre duas pessoas do que esta? Sem mencionar que o que a exaspera em Fabiano é justamente sua falta de iniciativa em arranjar as coisas de forma que se torne possível comprar uma cama de couro para remover algo que os afasta. Ela se irrita com ele, no limite, porque quer ficar mais próxima dele, com ronco e tudo.

A confiança de sinha Vitória em Fabiano, aliás, será revelada nos momentos mais difíceis. Não só no desacordo, mas também no que há de mais traumático - com exceção da seca ou de sua perspectiva - em todo o livro: a morte de Baleia. Enquanto ele se prepara para sacrificar a cachorrinha, ela fica dentro de casa, para segurar e consolar os dois meninos. Seu desespero, no entanto, não era menor do que o deles, o que se manifesta no esforço que faz para ao mesmo tempo segurar os filhos, tampar-lhes os ouvidos e tampar seus próprios ouvidos. Mas nem por um átimo se revolta contra a decisão do marido: "naturalmente a decisão de Fabiano era necessária e justa" (pp. 128-9).

Da parte de Fabiano não é diferente. No primeiro capítulo, além do abraço, no plano mais objetivo, confirma seu desejo por ela a projeção de futuro que desenha:

Sinha Vitória vestiria uma saia larga de ramagens. A cara murcha de sinha Vitória remoçaria, as nádegas bambas de sinha Vitória engrossariam, a roupa encarnada de sinha Vitória provocaria a inveja das outras caboclas (p. 17).

Essa projeção não se alimenta propriamente da imaginação, mas da memória. Fabiano, ao contemplar o futuro quando ele ainda é incerto - nem choveu ainda - , vê a imagem da sinha Vitória que ele já conhece, a imagem do que ela era antes da seca. E ele 
faz isso tendo diante de si a figura esquálida do presente. É nesse corpo sem carne que ele projeta os corpos cheios - o do passado e o do futuro. Para Fabiano, sinha Vitória será novamente bela com o rosto remoçado; desejável, com as nádegas engrossadas; e elegante, com roupas de causar inveja.

É claro que, na vida prática, no calor de uma discussão - exatamente sobre a cama - Fabiano externará opinião muito diferente dessa. Ela acusa o marido de gastar excessivamente com jogo e cachaça, atingindo-o de forma certeira, porque é algo de que ele próprio se culpa. Em resposta ele dirá que o dinheiro se foi por causa dos sapatos de verniz dela e, com a crueldade típica dos culpados, afirma que, com eles, ela "mexia-se como um papagaio, era ridícula" (p. 58). Justo ele que, quando vai à festa de Natal na cidade, percebe que sua roupa mal cortada é ridícula, "mas não queria pensar nisto" (p. 115). Fabiano não a considera ridícula, mas, na ânsia de se livrar da responsabilidade, é claramente injusto tanto com ela quanto consigo mesmo, e se permite uma "sinceridade" a que somente as relações muito consolidadas resistem. Ela, é evidente, ofende-se, "e, se não fosse o respeito que Fabiano lhe inspirava, teria despropositado" (p. 58). Mas não só: "Devia ser ridícula, mas a opinião de Fabiano entristecera-a muito" (p. 58). A consideração que ela tem por ele se reafirma, se não pelo respeito que lhe reprime a reação, pela tristeza - algo muito diferente do desejo de despropositar de se ver ridícula através dos olhos dele, mesmo que se perceba assim, certamente por normalmente se ver, aliás como ele próprio, pelos olhos dos "brancos". A tristeza de sinha Vitória paradoxalmente os mantém intimamente conectados.

Num outro plano, a avaliação altamente positiva que ele faz da inteligência da mulher é tão explícita que quase dispensa comentários. Em "O mundo coberto de penas", ela faz a observação de que as aves da arribação matam o gado. Fabiano, desabituado da linguagem figurada, peleja longamente com as palavras e o raciocínio até se aperceber de que ela não se refere a um ataque direto das aves, mas sim a algo mais sutil: na iminência da seca, aos bandos, elas contribuiriam para que a água secasse, e a falta de água mataria o gado.

Agora Fabiano percebia o que ela queria dizer. Esqueceu a infelicidade próxima, riuse encantado com a esperteza de sinha Vitória. Tinha ideias, sim senhor, tinha muita coisa no miolo. Nas situações difíceis encontrava saída (pp. 168-9).

Mais do que admirar a inteligência da mulher, ao perceber sua manifestação Fabiano se retira do mundo - a infelicidade que ele esquece é a maior delas, é o grande temor, a seca. 
Em "Contas" também a inteligência de sinha Vitória é mobilizada, mas em vão. As contas que ela faz laboriosamente com o auxílio de diferentes grãos estão certas, mas erra porque não leva em conta aquilo que está fora do alcance deles compreender: os juros ou o que quer que o patrão atribua aos juros. Mais uma vez, quando apertado, desta vez pelo patrão, que não aceita os cálculos que lhe são apresentados e o ameaça, Fabiano acaba declarando algo em que não crê: "Devia ser ignorância da mulher, provavelmente devia ser ignorância da mulher. Até estranhara as contas dela" (p. 141).

No entanto, depois do acerto, desejoso de entrar na bodega para beber uma cachaça, mas temeroso de repetir a experiência com o soldado amarelo porque "às vezes dizia uma coisa sem intenção de ofender, entendiam outra, e lá vinham questões" (p. 147), ele dirá: "o único vivente que o compreendia era a mulher. Nem precisava falar: bastavam os gestos" (pp. 147-8). Assim, logo depois de negar para os outros o traço que mais admira na mulher, Fabiano confessa que há entre eles a mais profunda das formas de compreensão humana, aquela que dispensa as palavras - tão mais decisiva num meio em que as palavras escasseiam e mais parecem obstáculos do que forma de ligação entre as pessoas.

Como se vê, a relação de sinha Vitória e Fabiano é composta de desejo, admiração, respeito e compreensão. Mas isso misturado com a raiva, as decepções e injustiças causadas pelos choques cotidianos ou pelas fraquezas que toda gente tem. $\mathrm{O}$ banho e o monturo. E é isso que caracteriza o amor que talvez não pareça amor, aquele que é feliz e portanto não tem história: ser posto à prova dia a dia e se reafirmar por meio da capacidade de se manter ativo.

\section{4.}

Mas ainda falta tratar de um outro elemento que compõe esse amor. Aquilo que Luís da Silva se permite almejar ao ver-se alçado à posição de protetor de Marina, com algum dinheiro no banco e ocupações estáveis. Aquilo que ultrapassa o indivíduo e o projeta para fora de si: os filhos e os projetos comuns.

E, em Vidas secas, o primeiro projeto comum que os liga é o da sobrevivência. Nesse sentido, fazem tudo juntos, em comum acordo. Discutem as contas, planejam no que vão gastar, afligem-se, felizes, com a enchente. Mas é no capítulo final, "Fuga", que esse projeto salta para o primeiro plano. Ao iniciar-se um novo período de seca, eles estão diante do maior medo e da maior ameaça. Não podem prever o que os aguarda, a 
não ser padecimento e a duvidosa sobrevivência. Fabiano, que ali é o forte, tem dúvidas, teme não conseguir, sinha Vitória também:

Os pés calosos, duros como cascos, metidos em alpercatas novas, caminhariam meses. Ou não caminhariam? Sinha Vitória achou que sim. Fabiano agradeceu a opinião dela e gabou-lhe as pernas grossas, as nádegas volumosas, os peitos cheios. As bochechas de sinha Vitória avermelharam-se e Fabiano repetiu com entusiasmo o elogio. Era. Estava boa, estava taluda, poderia andar muito. Vitória riu e baixou os olhos. Não era tanto como ele dizia não (p. 189).

Numa cena em que se revive um clima dengoso, de início de namoro, os elogios trocados têm duplo alcance. Por um lado reafirmam a força de Fabiano e a beleza de sinha Vitória, o interesse de um pelo outro. E também servem de apoio, incentivo, consolo e prenúncio de sucesso na hora de começar a enfrentar o desafio da sobrevivência que se renova e, em princípio, seria pessoal, já que ninguém morre acompanhado. Em mais uma mistura de elementos aparentemente díspares, o grau de solidez do amor se confirma.

Quanto aos filhos, o que talvez chame a atenção à primeira vista do leitor de hoje seja a violência dessa relação, especialmente acentuada em "O menino mais velho". São reprimendas, cocorotes e puxões de orelha constantes, sempre porque alguém "não conversou um instante com o menino" (p. 81), para ficar próximo do período de abertura desse capítulo. Mas em Vidas secas há um elemento importante, que complica a vida de quem quiser ver em Fabiano e sinha Vitória a simples brutalidade. O narrador dá acesso ao ponto de vista dos adultos. Em Infância, por exemplo, o grau de violência é muito maior, o que se deve à violência dos atos em si, é claro, surras monstruosas, mas também porque são narrados por quem sofreu as surras e não consegue atinar com as razões que lhes deram origem. É assim que a mãe ferira o filho com a corda cheia de nós porque estava "irritada" e o pai já levanta da rede de "mau humor" antes de sentir falta de um cinto e punir cruelmente o filho que nada fizera. ${ }^{12}$

Em Vidas secas, quando o ponto de vista é o do menino mais velho, ocorre aparentemente o mesmo. ${ }^{13} \mathrm{O}$ capítulo dedicado a ele é todo ocupado com esse embate.

12. Ver: Ramos, Graciliano. Infância. Rio de Janeiro: José Olympio, 1945. Aqui se faz referência ao capítulo "Um cinturão", pp. 31-6.

13. O menino mais novo não, está noutra fase. Ele ainda não faz perguntas, antes admira o pai e o considera, vendo-o de gibão, "a criatura mais importante do mundo" (p. 69); na noite que acompanhamos 
Cheio de curiosidade que os adultos não têm paciência de atender, sofre a incompreensão e, mais que isso, é invadido por um sentimento desconfortável de inquietude. Só desejava conhecer o significado da palavra "inferno", faz uma pergunta que a mãe considera insolente e leva mais um cocorote por causa disso. O curioso é que não é propriamente a incompreensão ou os cocorotes sofridos que deixarão seu espírito em grande atribulação. Esses, ele atribui, como em Infância, à má disposição dos adultos: "achava as pancadas naturais quando as pessoas grandes se zangavam" (p. 87).

É certo que a incompreensão e a violência abrem caminho para a melancolia que experimenta ao final do capítulo, mas, paradoxalmente, é a resposta de sinha Vitória e não sua recusa em responder - que o deixará assim. Ele inicia o capítulo na melhor das disposições, confiante na estabilidade em que a família vive. Adicionalmente, suas lembranças da seca são difusas, o que lhe permite pensar que "todos os lugares conhecidos eram bons" (p. 85). Sua confiança é tão sólida que mesmo os lugares distantes não o inquietam. Ele sabe que há várias coisas além deles, a começar pela serra distante. Mas sua percepção é a de que "esses mundos viviam em paz, às vezes desapareciam as fronteiras, habitantes dos dois lados entendiam-se perfeitamente e auxiliavam-se" (p. 85). No entanto, sinha Vitória lhe descreve um lugar horrível, um lugar que ele compreende como concreto. Ora, essa possibilidade não havia sido aventada por ele, e acaba por trazer-lhe do fundo da memória a experiência passada: "Entristeceu. Talvez sinha Vitória dissesse a verdade. O inferno devia estar cheio de jararacas e sussuaranas, e as pessoas que moravam lá recebiam cocorotes, puxões de orelhas e pancadas com a bainha da faca" (p. 89). Ora, a única vez que recebera pancadas com a bainha da faca fora quando se recusara a continuar andando, no primeiro capítulo ao final da seca. Mais do que um lugar horrível, o inferno é um lugar que ele, ao contrário do que quer admitir sinha Vitória, já visitou.

De toda maneira, quando o ponto de vista de um adulto é evocado, a relação entre pais e filhos ganha um outro aspecto porque o que parece arbitrário à criança tem pelo menos uma explicação - o que não ameniza nem a violência nem a incompreensão, mas explica suas origens. E isso acontece logo naquela cena de abertura do romance involuntariamente evocada pelo menino mais velho, quando ele, fraco e exausto, recusa-se a prosseguir e se senta no chão. A primeira reação de Fabiano é xingá-lo de "condenado do diabo" (p. 8). A violência verbal logo chega à física: "fustigou-o com a bainha da faca

em "Inverno", satisfaz-se plenamente com os casos contados por Fabiano. Ao contrário do irmão mais velho, que se irrita com as incongruências e as lacunas das narrativas. 
de ponta" (p. 8). E numa rapidez inesperada, está transformada no desejo da máxima violência: "O pirralho não se mexeu, e Fabiano desejou matá-lo. Tinha o coração grosso, queria responsabilizar alguém pela sua desgraça” (p. 8). O mecanismo psicológico mais recorrente em Fabiano é mobilizado: precisa responsabilizar alguém pelo que o aflige, assim como faria acerca dos sapatos de sinha Vitória. O desejo de morte não cessa e "pelo espírito atribulado do sertanejo passou a ideia de abandonar o filho naquele descampado" (p. 9). Mas pensa nos urubus, sinha Vitória intervém indicando uma direção como se estivessem próximos de algum lugar, e ele, com a fúria contida, toca o filho e sente que ele está "frio como um defunto" (p. 9). E nesse momento tudo se dissolve: "Aí a cólera desapareceu e Fabiano teve pena. Impossível abandonar o anjinho aos bichos do mato" (p. 9). E esse diminutivo, o primeiro dos poucos empregados no livro - o segundo aparece em seguida porque os "bracinhos" da criança caíam de fraqueza —, inunda o texto de afeto. Diante da possibilidade concreta da morte do filho, entrevista na frieza de cadáver, fica claro que é mesmo um desafogo o pensamento de Fabiano - ele próprio em situação extrema. Quando incomoda, ameaça a sobrevivência, o menino fica distante e se converte em traste a ser abandonado. Mas a concretude do contato físico restabelece a ligação, e a morte planejada ganha também concretude e se torna insuportável. E tudo isso é evocado pelo emprego de um diminutivo, "anjinho", utilizado tanto para designar a inocência das crianças vivas como a morte dos inocentes, e por si só aponta os limites entre vida e morte da situação. Ali não está mais "o pirralho".

Esse afeto recuperado contamina o restante do capítulo. A partir dali, nos pensamentos do vaqueiro, a mulher e os filhos acorrem a sua mente antes de si mesmo. Baleia consegue pegar o preá e todos se mobilizam para assá-lo. Feito o fogo, Fabiano vai procurar água. Encontra e bebe. Demora-se observando o céu, onde localiza cirros ao poente. Não comera nada o dia todo. No dia anterior tudo o que comera fora um papagaio, dividido entre quatro pessoas e a cachorra. Mas ali, permitindo-se ser alegre, ele "pensou na família, sentiu fome" (p. 15). E, um pouco adiante, mais uma vez a família precederá a visão da comida: "Lembrou-se dos filhos, da mulher e da cachorra, que estavam lá em cima, debaixo de um juazeiro, com sede. Lembrou-se do preá morto" (p. 16). Primeiro a família, depois a fome; primeiro a família, depois a comida.

No capítulo seguinte, "Fabiano", vemos o chefe da família em sua lida diária. Em princípio, pensamos que ele está só. Mas eis que o narrador nos informa que "os três pares de alpercatas batiam na lama rachada" (p. 22). Os meninos o acompanham, e lá vem o incômodo: "Uma das crianças aproximou-se, perguntou-lhe qualquer coisa. Fabiano parou, franziu a testa, esperou de boca aberta a repetição da pergunta. Não 
percebendo o que o filho desejava, repreendeu-o" (p. 25). Sabemos, portanto, que mais uma vez Fabiano lança nas costas de outro uma falha que é sua, a de simplesmente não compreender o que o menino perguntava. Mas isso o leva a pensamentos e atos imprevistos, que nada têm a ver consigo próprio. Primeiro se pergunta acerca da criança: "se continuasse assim, metido com o que não era da conta dele, como iria acabar?” (p. 26). Moldado na subalternidade, Fabiano também se preocupa com a sorte do filho porque o vê em posição semelhante, tendo que se conformar com ela. Evoca a própria infância e se revê perguntador como o filho. Nesse momento, o que era desafogo da própria ignorância transforma-se em preocupação genuína, que o faz aproximar-se: "Chamou os filhos, falou de coisas imediatas, procurou interessá-los" (p. 26). Mas vai além e cria uma pedagogia da concretude ao gritar para a cachorra, simulando a busca de uma novilha, mostrando com isso na prática como se faz o trabalho: "Queria apenas dar um ensinamento aos meninos" (p. 26). O pensamento de Fabiano se dispersa por muitos outros caminhos no decorrer desse capítulo, mas é com a preocupação com os filhos que ele se encerrará: "falaria com sinha Vitória a respeito da educação dos meninos" (p. 33).

O que desponta, ao final desse segundo capítulo, é o outro projeto que Fabiano partilha com a mulher, a preparação do futuro dos filhos. Ele não decide nada sozinho, falará com ela. Projeto que incorpora o amor feliz que eles vivem. Amor feliz não é amor despreocupado. No amor que está ausente de Vidas secas, os meninos não são os amantes, assim, não teriam qualquer relação com o sentimento íntimo que partilham. Mas no amor diferente de Vidas secas elementos externos podem não ser apenas externos e ocupar função determinante nessa mistura de que ele se constitui.

E é dessa maneira que o projeto amoroso de preparação do futuro dos filhos tem um forte impacto no desfecho do romance, frequentemente qualificado de pessimista. $\mathrm{Na}$ iminência de uma nova seca, o futuro será debatido quando mais ameaçado está. Para Fabiano, em princípio, há clareza. É preciso ensinar aos meninos a lida com o gado e a subserviência. O excesso de interesse por aquilo que se passa fora dos limites dessa vida é dispersão e perigo. Mas ocorre que, no início da fuga, os meninos gozam de boa saúde e de disposição e, apesar de ressabiados, correm. Mas param para contemplar os montes ao longe e sinha Vitória faz a Fabiano uma pergunta banal: "Em que estariam pensando?" (p. 190). Fabiano julga que menino é "bicho miúdo, não pensa" (p. 190), mas a mulher discorda. E, como ele confia no tino dela, tem sua convicção abalada. É assim que pela primeira vez eles cogitam uma vida diferente. Sinha Vitória faz nova pergunta, "desejava saber que iriam fazer os filhos quando crescessem" (p. 190). A resposta de Fabiano é a que se esperava: "Vaquejar" (p. 19o). Sinha Vitória se opõe. Como 
encontrar a felicidade em semelhante modo de vida? E projeta: "Fixar-se-iam muito longe, adotariam costumes diferentes" (p. 190).

Como a demonstrar que as coisas não estão destinadas a ser sempre as mesmas, após uma pausa, ao pegarem seus pertences para prosseguir a viagem, sinha Vitória retira uma cuia que estava presa ao cinto do marido e a coloca na cabeça do menino mais velho, que a carregará. E ficamos sabendo que "Fabiano aprovou o arranjo" (p. 195). Essa frase ecoa uma outra, do primeiro capítulo. Lá, é Fabiano quem precisa assumir um peso a mais, o do próprio menino que se recusa a marchar. Ele entrega a espingarda à mulher e levanta o filho, para carregá-lo, e "Sinha Vitória aprovou esse arranjo" (p. 9). O gesto é dúbio. Num primeiro momento, pode ser entendido como continuidade, uma vez que sugere a repetição, por uma outra geração, dos atos da anterior, assim como Fabiano repete o andar desajeitado do avô e do pai. Mas também pode ser compreendido como ruptura porque é sinha Vitória quem faz o gesto, é ela quem coloca o filho em nova posição, é ela quem o converte de peso em alívio, assim como fora ela quem sugerira uma vida noutra parte.

O deslocamento não é grande: na verdade é quase imperceptível. Mas isso está de acordo com o alívio sentido pelo vaqueiro. Afinal, o narrador dirá, como se nos revelasse como as coisas são: "O peso da cuia era uma insignificância". Só que ficaremos sabendo também como elas são vistas pelo personagem: "mas Fabiano achou-se leve" (p. 195).

E Fabiano vê as coisas, nesse momento, filtradas pela mudança, uma visão construída amorosamente em conjunto com sinha Vitória: "Repetia docilmente as palavras de sinha Vitória, as palavras que sinha Vitória murmurava porque tinha confiança nele" (p. 196). E o narrador - que sempre evitou interferir - insistirá, voz da autoridade que é, em fechar a narrativa dizendo como as coisas são, que a vida deles, mesmo que seu projeto vingue, pouco mudará. O pessimismo, portanto, é dele - e não do livro como um todo - porque pela primeira vez se insinua na mente daquelas pessoas um projeto maior do que o de simplesmente sobreviver. Um projeto nascido da experiência concreta de um amor constituído de coisas contraditórias entre as quais, agora, também se inclui a esperança.

Luís Bueno é professor da Universidade Federal do Paraná e autor de Uma história do romance de 30 [Edusp/ Editora Unicamp, 2006]. 